\title{
The Listen List 2013
}

\section{The Listen List: Outstanding Audiobook Narration Council}

The list was selected by The Listen List: Outstanding Audiobook Narration Council, whose members include Neal Wyatt, chair, Virginia Commonwealth University; Jodi L. Israel, library technology expert and veteran audiobook reviewer, Birmingham, Alabama; Bonnie Kunzel, youth services and adolescent literacy consultant, Germantown, Tennessee; Joyce Saricks, Dominican University, River Forest, Illinois; Kaite Mediatore Stover, Director of Readers' Services, The Kansas City (MO) Public Library; and Renee Young, Novelist Audiobook project team lead, Durham, North Carolina.
$\mathbf{T}$

he Reference and User Services Association (RUSA) has announced its selection for the 2013 Listen List: Outstanding Audiobook Narration juried list. Established in 2010 by the Collection Development and Evaluation Section (CODES) of RUSA, the council seeks to highlight extraordinary narrators and listening experiences that merit special attention by general adult listeners and the librarians who work with them. Titles are selected because they are a pleasure to listen to and make one reluctant to stop listening; because the narration of the book creates a new experience, offering listeners something they could not create by their own visual reading; and because the narrator achieves an outstanding performance in terms of voice, accents, pitch, tone, inflection, rhythm, and pace. This year's list, designed for avid listeners and those new to the joys of being read a story, includes fiction and nonfiction and features voices that enthrall, delight, and inspire.

\section{THE 2013 WINNERS}

Davis, Miles and Quincy Troupe. Miles: The Autobiography. Narrated by Dion Graham. AudioGO. (ISBN: 978-0-79278481-4).

With his raspy, whispery voice Dion Graham inhabits musical genius Miles Davis in this tell-all autobiography that flows like a jazz riff. While setting the record straight about Davis's career, lovers, addiction, and racial issues, Graham channels Davis's voice and cadence so completely that listeners will believe they're hearing the master himself.

\section{Listen-Alikes}

Chabon, Michael. Telegraph Avenue. Narrated by Clarke Peters. Harper Audio; Recorded Books.

Ebert, Roger. Life Itself. Narrated by Edward Herrmann. Hachette Audio; AudiGO.

Richards, Keith. Life. Narrated by Keith Richards, Johnny Depp, and Joe Hurley. Hachette Audio.

Dickens, Charles. The Pickwick Papers. Narrated by David Timson. Naxos Audiobooks. (ISBN: 978-1-8437-9555-1).

Timson's irrepressible performance of this rollicking romp through 1830s England in Dickens's first novel invites listeners along as Pickwick and his crew ramble through the countryside. With broad satire and clever irony, Timson proves a delightful guide through slapdash adventures and a host of eccentric characters. 


\section{FROM COMMITTEES OF RUSA}

\section{Listen-Alikes}

Adams, Douglas. The Hitchhiker's Guide to the Galaxy. Narrated by Stephen Fry. Books on Tape.

Chaucer, Geoffrey. The Canterbury Tales. Narrated by a full cast. Blackstone Audio.

Joyce, Rachel. The Unlikely Pilgrimage of Harold Fry. Narrated by Jim Broadbent. Books on Tape.

Harkaway, Nick. Angelmaker. Narrated by Daniel Weyman. AudioGO. (ISBN: 978-0-7927-8486-9).

In a gravelly yet gleeful voice, Weyman narrates this swashbuckling genre-blend of spies, gangsters, and a doomsday machine. The lavish and imaginative story of Joe Spork, a clockmaker out of his depth as he attempts to save the world, is brilliantly realized through Weyman's attention to inflection, characterization, and pacing.

\section{Listen-Alikes}

Clarke, Susanna. Jonathan Strange and Mr. Norrell. Narrated by Simon Prebble. Sound Library/BBC Audiobooks America.

Fforde, Jasper. One of Our Thursdays is Missing. Narrated by Emily Gray. Recorded Books.

Willis, Connie. To Say Nothing of the Dog, or, How We Found the Bishop's Bird Stump at Last. Narrated by Steven Crossley. Recorded Books.

Horowitz, Anthony. The House of Silk: A Sherlock Holmes Novel. Narrated by Derek Jacobi. Hachette Audio. (ISBN: 978-16111-3689-0). AudioGO. (ISBN: 978-1-6111-3290-8).

In a refined, resonant, and delightfully self-aware voice, Jacobi re-creates the world of Sherlock Holmes. His pacing is lovely-leisurely, inviting, and seductive-while his accents are grand and fit the characters perfectly. In this authorized addition to the canon, Holmes investigates a conspiracy linking criminals to the highest levels of government.

\section{Listen-Alikes}

Doyle, Arthur Conan, Sir. The Hound of the Baskervilles. Narrated by Simon Prebble. Tantor Audio.

Perry, Anne. The Face of a Stranger. Narrated by Davina Porter. Recorded Books.

Todd, Charles. A Test of Wills. Narrated by Samuel Gillies. Recorded Books.

Ishiguro, Kazuo. The Remains of the Day. Narrated by Simon Prebble. Tantor Media. (ISBN: 978-1-4526-0835-8).

Prebble's performance is like listening to a full cast production so great is his skill in crafting characters. Navigating memories of both "upstairs" and "downstairs," dutiful butler Stevens revisits past pains and triumphs. Prebble creates a poignant reflection of a life given to service seen through the eyes of a man finally questioning his purpose.

\section{Listen-Alikes}

Begley, Louis. About Schmidt. Narrated by George Guidall. Recorded Books.

McEwan, Ian. Saturday. Narrated by Steven Crossley. Recorded Books.

Wharton, Edith. The House of Mirth. Narrated by Anna Fields. Blackstone Audiobooks.

Mantel, Hilary. Bring Up the Bodies. Narrated by Simon Vance. Macmillan Audio. (ISBN: 978-1-4272-2582-5).

In this grim and gripping tale, masterfully told, Vance brings Tudor England to life. Beautifully accented and paced, his pitch-perfect narration deftly navigates the large and diverse cast and the intricate plot machinations to create a stunning glimpse into a dangerous time when Henry VIII ruled and Thomas Cromwell served as his "fixer."

\section{Listen-Alikes}

George, Margaret. Elizabeth I. Narrated by Kate Reading. Books on Tape.

Mallon, Thomas. Watergate. Narrated by Joe Barrett. Blackstone Audio.

Sansom, C. J. The Matthew Shardlake series. Narrated by Steven Crossley. Recorded Books.

Moore, Liz. Heft. Narrated by Kirby Heyborne and Keith Szarabajka. Blackstone Audiobooks. (ISBN: 978-1-4551-6015-0).

This magnificent dual narration illuminates a poignant story of the isolation, family relationships, and new beginnings of two lost souls on a collision course. Szarabajka's richly sonorous voice captures morbidly obese Arthur's physical and emotional weight, while Heyborne's quietly expressive voice exposes the desperation of the teenaged Kel.

\section{Listen-Alikes}

Donoghue, Emma. Room. Narrated by Michal Friedman, Ellen Archer, Suzanne Toren, and Robert Petkoff. Hachette Audio.

Harbach, Chad. The Art of Fielding. Narrated by Holter Graham. AudioGO.

Oates, Joyce Carol. We Were the Mulvaneys. Narrated by Scott Shina. Recorded Books.

O'Connell, Carol. The Chalk Girl. Narrated by Barbara Rosenblat. Recorded Books. (ISBN: 978-1-4640-2018-6).

The discovery of a blood-covered little girl wandering in Central Park draws police detective Kathleen Mallory into an investigation involving long hidden secrets of New York's elite. Rosenblat's warmly expressive voice embodies each character effortlessly while adroitly managing the pace of Mallory's gritty and harrowing tenth case.

\section{Listen-Alikes}

Box, C.J. Blue Heaven. Narrated by John Bedford Lloyd. Macmillan Audio. 
Connelly, Michael. The Drop. Narrated by Len Cariou. Recorded Books.

Paretsky, Sara. Breakdown. Narrated by Susan Ericksen. Brilliance Audio.

Shakespeare, William. Macbeth. Narrated by Alan Cumming. Simon \& Schuster Audio. (ISBN: 978-1-4423-5593-4).

Cumming makes "The Scottish Play" an electric event, allowing modern audiences a chance to experience it with the same excitement, horror, and wonder Shakespeare's contemporary audiences surely felt. From stage directions delivered in furtive whispers to the cackle of the witches and the grim resolution of Lady Macbeth, Cumming astounds.

\section{Listen-Alikes}

Dickens, Charles. A Christmas Carol. Narrated by Jim Dale. Listening Library.

Homer. The Odyssey. Narrated by Stanley Lombardo and Susan Sarandon. Parmenides Audio.

Shakespeare, William. King Lear. Narrated by a full cast. Naxos Audiobooks.

Sloan, Robin. Mr. Penumbra's 24-Hour Bookstore. Narrated by Ari Fliakos. Macmillan Audio. (ISBN: 978-1-4272-2742-3).

Affectionate and playful, Ari Fliakos' narration is addictive as he expertly voices full-bodied characters, savoring their eccentricities, in this imaginative work of "geek-lit." His optimistic wonder and understanding of the subtext bring tension to even the minutiae of this grand quest by a motley crew of book lovers hoping to crack the code of immortality.

\section{Listen-Alikes}

Cline, Ernest. Ready Player One. Narrated by Wil Wheaton. Random House Audio; Books on Tape.

Pearl, Matthew. The Technologists. Narrated by Stephen Hoye. Random House Audio; Books on Tape.

Ruiz Zafon, Carlos. The Shadow of the Wind. Narrated by Jonathan Davis. Penguin Audiobooks.

Smith, Mark Allen. The Inquisitor. Narrated by Ari Fliakos. Macmillan Audio. (ISBN: 978-1-4272-1477-5).

Fliakos' unflinching depiction of Geiger, an expert in the art of "information retrieval" (aka torture), intensifies this absorbing and disturbing thriller. He sets the mood from the opening line, offering a tormented, affectless, but surprisingly sympathetic hero. His skill in creating tone, character, and pace enhances the haunting quality of Geiger's world.

\section{Listen-Alikes}

Cook, Thomas H. The Cloud of Unknowing. Narrated by Stephen Hoye. Tantor Audio.

Rendell, Ruth. 13 Steps Down. Narrated by Ric Jerrom. BBC Audiobooks America.

Walters, Minette. The Chameleon's Shadow. Narrated by Simon Vance. Tantor Audio.

Willig, Lauren. The Garden Intrigue. Narrated by Kate Reading. Books on Tape. (ISBN: 978-0-3079-8994-9).

In this lively ninth Pink Carnation romp, Eloise and Colin are beset by a film crew, while in the nineteenth century, agent Augustus Whittlesby, an infamously bad poet, investigates rumors of Napoleon's plotting and encounters love. Reading's companionable, husky voice reveals all the humor in the rich banter and bad verse, as well as the passion.

\section{Listen-Alikes}

Bourne, Joanna. The Spymaster's Lady. Narrated by Kirsten Potter. Penguin Audio.

Phillips, Susan Elizabeth. Natural Born Charmer. Narrated by Anna Fields. Books on Tape.

Quinn, Julia. What Happens in London. Narrated by Rosalyn Landor. Books on Tape.

Daniel Woodrell. The Death of Sweet Mister. Narrated by Nicholas Tecosky. AudioGo. (ISBN: 978-1-6111-3001-0).

Welcome to the world of Shug Akins, a thirteen-year-old loner coming of age in the Ozarks. Tecosky skillfully demonstrates that the vernacular of this country noir novel is at its lyrical best when spoken aloud. In a youthful detached voice, he authentically captures the violence, poverty, and heartbreaking bleakness of Shug's life.

\section{Listen-Alikes}

Clinch, Jon. Finn. Narrated by Ed Sala. Recorded Books. McKinty, Adrian. The Cold, Cold Ground. Narrated by Gerard Doyle. Blackstone Audio.

Torres, Justin. We the Animals. Narrated by Frankie J. Alvarez. Blackstone. 